\title{
APP transgenic modeling of Alzheimer's disease: mechanisms of neurodegeneration and aberrant neurogenesis
}

\author{
Leslie Crews • Edward Rockenstein • \\ Eliezer Masliah
}

Received: 22 September 2009/Accepted: 11 November 2009/Published online: 29 November 2009

(C) The Author(s) 2009. This article is published with open access at Springerlink.com

\begin{abstract}
Neurodegenerative disorders of the aging population affect over 5 million people in the US and Europe alone. The common feature is the progressive accumulation of misfolded proteins with the formation of toxic oligomers. Alzheimer's disease (AD) is characterized by cognitive impairment, progressive degeneration of neuronal populations in the neocortex and limbic system, and formation of amyloid plaques and neurofibrillary tangles. Amyloid- $\beta(\mathrm{A} \beta)$ is the product of proteolysis of amyloid precursor protein (APP) by $\beta$ and $\gamma$-secretase enzymes. The neurodegenerative process in $\mathrm{AD}$ initiates with axonal and synaptic damage and is associated with progressive accumulation of toxic $\mathrm{A} \beta$ oligomers in the intracellular and extracellular space. In addition, neurodegeneration in $\mathrm{AD}$ is associated with alterations in neurogenesis. $\mathrm{A} \beta$ accumulation is the consequence of an altered balance between protein synthesis, aggregation rate, and clearance. Identification of genetic mutations in APP associated with familial forms of $\mathrm{AD}$ and gene polymorphisms associated with the more common sporadic variants of $\mathrm{AD}$ has led to the development of transgenic (tg) and knock out rodents as well as viral vector driven models of AD. While APP tg murine models with mutations in the Nand $\mathrm{C}$-terminal flanking regions of $\mathrm{A} \beta$ are characterized by increased $\mathrm{A} \beta$ production with plaque formation, mutations in the mid-segment of $\mathrm{A} \beta$ result in increased formation of oligomers, and mutations toward the C-terminus (E22Q)
\end{abstract}

L. Crews · E. Masliah

Department of Pathology, University of California,

San Diego, La Jolla, CA, USA

E. Rockenstein · E. Masliah $(\bowtie)$

Department of Neurosciences, University of California,

San Diego, 9500 Gilman Drive, La Jolla, CA 92003-0624, USA

e-mail: emasliah@ucsd.edu segment results in amyloid angiopathy. Similar to $\mathrm{AD}$, in APP tg models bearing familial mutations, formation of $\mathrm{A} \beta$ oligomers results in defective plasticity in the perforant pathway, selective neuronal degeneration, and alterations in neurogenesis. Promising results have been obtained utilizing APP tg models of AD to develop therapies including the use of $\beta$ - and $\gamma$-secretase inhibitors, immunization, and stimulating neurogenesis.

Keywords Transgenic - Neurodegenerative disease . Aging $\cdot$ Alzheimer $\cdot$ APP $\cdot$ Synapse loss $\cdot$ Neurogenesis

\section{Introduction}

Alzheimer's disease (AD) is the most common neurodegenerative disorder in the aging population. It is characterized by the progressive and irreversible deafferentation of the limbic system, association neocortex, and basal forebrain (Perry et al. 1977; Hyman et al. 1984; Wilcock et al. 1988; Hof et al. 1990; Palmer and Gershon 1990; Masliah et al. 1993), accompanied by the formation of neuritic amyloid plaques, amyloid angiopathy, neurofibrillary tangles (NFTs), and neuropil threads (Terry et al. 1994). This neurodegenerative process is followed by reactive astrogliosis (Dickson et al. 1988) and microglial cell proliferation (Rogers et al. 1988; Masliah et al. 1991).

Loss of synapses (DeKosky and Scheff 1990; Masliah 2001; Scheff and Price 2001) and axonal pathology (Raff et al. 2002) are probably key neuropathological features leading to dementia in these neurodegenerative disorders. In addition, recent evidence suggests that alterations in the niches for neurogenesis in the adult brain might also contribute to the neurodegenerative process (Haughey et al. 2002; Tatebayashi et al. 2003; Dong et al. 2004; 
Fig. 1 Schematic diagram of APP processing and accumulation of toxic $\mathrm{A} \beta$ species. $\beta$ - and $\gamma$-secretase cleavage of APP results in the production of $\mathrm{A} \beta_{1-40}$ and $\mathrm{A} \beta_{1-42}$, which accumulates into neurotoxic oligomers

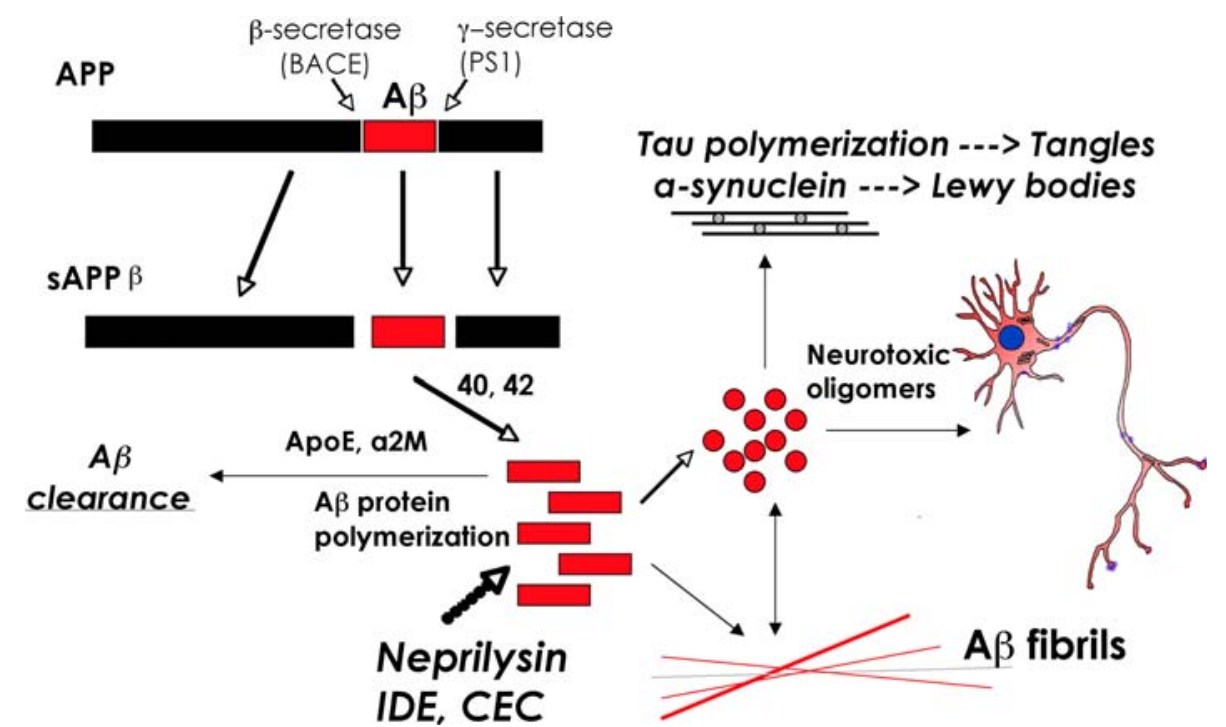

Jin et al. 2004; Wen et al. 2004; Chevallier et al. 2005; Donovan et al. 2006). The unique patterns of cognitive impairment that characterize $\mathrm{AD}$, in turn, depend on the neural circuitry specifically affected (Hof and Morrison 1994), the extent of the synapto-dendritic damage, and the speed with which the injury propagates (Terry et al. 1991; DeKosky et al. 1996). Recent evidence supports the contention that neuronal cell death might occur later in the progression of neurodegeneration and that damage to the synapto-dendritic apparatus might be one of the earliest pathological alterations (Masliah and Terry 1993, 1994; Masliah 1998, 2001; Honer 2003; Scheff and Price 2003). This is accompanied by the abnormal accumulation of neuronal proteins in the extracellular space (e.g., plaques, cerebral amyloid angiopathy [CAA]) or in intracellular compartments (e.g., tangles and Lewy bodies [LBs]). Abnormal accumulation and misfolding (toxic conversion) of these synaptic and cytoskeletal proteins are being explored as key pathogenic events leading to neurodegeneration (Koo et al. 1999; Ramassamy et al. 1999; Ferrigno and Silver 2000).

In $\mathrm{AD}$, amyloid- $\beta$ peptide $1-42\left(\mathrm{~A} \beta_{1-42}\right)$, a proteolytic product of amyloid precursor protein (APP) metabolism (Fig. 1), accumulates in the neuronal endoplasmic reticulum (ER) (Cuello 2005) and extracellularly (Selkoe et al. 1996; Trojanowski and Lee 2000; Walsh et al. 2000). The primary pathogenic event triggering synaptic loss and selective neuronal cell death in these disorders is not yet completely clear (Masliah 2000, 2001), however, recent studies suggest that nerve damage might result from the conversion of normally non-toxic monomers to toxic oligomers (Volles et al. 2001; Volles and Lansbury 2002; Walsh and Selkoe 2004) (Fig. 2), whereas larger polymers and fibers that often constitute the plaques might not be as toxic (Lansbury 1999; Walsh et al. 2002). An example of a

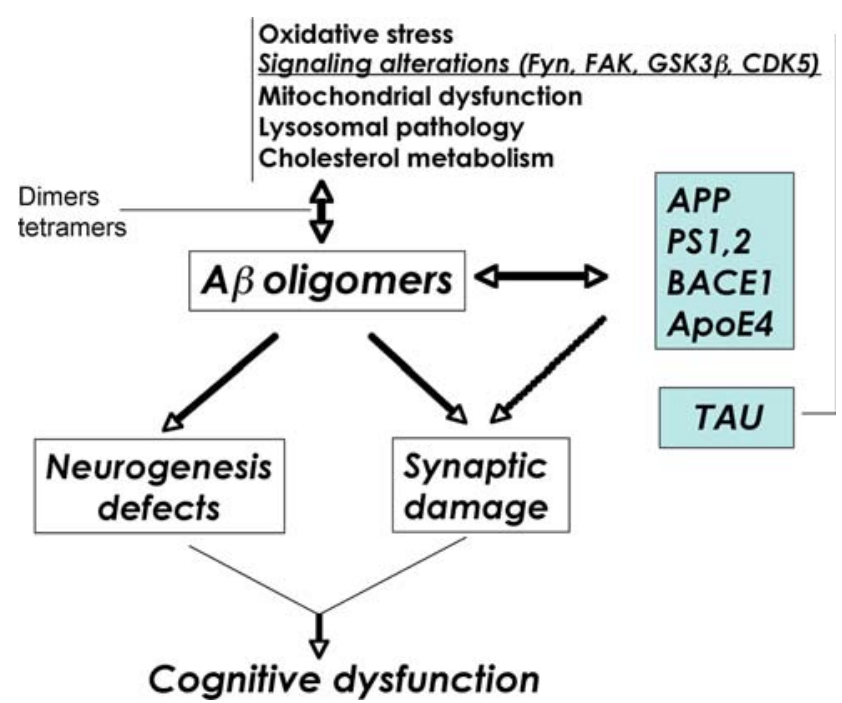

Fig. 2 Schematic diagram of factors contributing to $\mathrm{A} \beta$ oligomerization. Defective cellular processes can lead to the accumulation of $\mathrm{A} \beta$ dimers, trimers, and oligomers, which in turn contribute to neurogenesis defects and synaptic damage

naturally occurring oligomer species is $\mathrm{A} \beta * 56$, which has been shown to promote age-dependent memory deficits (Lesne et al. 2006). $\mathrm{A} \beta * 56$ and $\mathrm{A} \beta$ trimers secreted by cultured cells could share common synaptotoxic properties (Selkoe 2008). Previous studies have shown that the $\mathrm{A} \beta$ dimers, trimers, and higher-order oligomers secreted by cultured neurons inhibit LTP and damage spines (Klein et al. 2001; Walsh and Selkoe 2004; Townsend et al. 2006; Selkoe 2008). Additional studies have shown that $\mathrm{A} \beta$ dimers derived from human CSF disrupt synaptic plasticity and inhibit hippocampal LTP in vivo (Klyubin et al. 2008). Together, these studies indicate that $\mathrm{A} \beta$ oligomers ranging in size from 2 to 12 subunits might be responsible for the 
synaptic damage and memory deficits associated with $\mathrm{AD}$ (Lacor et al. 2007).

Thus, when developing transgenic (tg) models of $\mathrm{AD}$ it is important to consider the following outcome features: (1) targeting the selective neuronal populations in the neocortex and limbic system involved in learning and memory; (2) favoring production of high levels of $\mathrm{A} \beta_{1-42}$ over $\mathrm{A} \beta_{1-40}$; (3) promoting accumulation of $\mathrm{A} \beta$ oligomers; (4) inducing post-transcriptional modifications (e.g., pyroglutamate $\mathrm{A} \beta$ ); (5) evaluating abnormal accumulation of intracellular $\mathrm{A} \beta$; (6) evaluating development of amyloid plaques and CAA; (7) evaluating neurodegeneration with synaptic loss, axonal damage, and defects in neurogenesis; and (8) behavioral and electrophysiological impairments that correspond to the pattern of neurodegeneration.

\section{Experimental modeling of Alzheimer's disease}

Although dramatic progress has been made in understanding the pathogenesis of neurodegenerative conditions of the aged population, such as AD, Parkinson's disease (PD), and Lewy body disease (LBD), most of these disorders remain incurable. Because of the near epidemic proportion in the aging population, these disorders pose a serious challenge to the health care system. Identification of new targets and development of biological mouse models holds the promise of better understanding their pathogenesis and discovering and testing new treatments.

Experimental models of AD could mimic individual or multiple alterations found in $\mathrm{AD}$; however, to date not a single model mimics all the alterations observed in AD. The best model is probably the aged monkey (Price et al. 1994), however, because of the time and cost involved in utilizing this model, most studies have been focused on developing murine models. Most of the tg animal models of $\mathrm{AD}$ are based on the targeted overexpression of single or multiple mutant molecules associated with familial AD (FAD) (Table 1, Fig. 3). Currently, mutations in three genes have been described, namely APP, presenilin (PS)1, and PS2 (Hutton and Hardy 1997; Cruts and Van Broeckhoven 1998; Rocchi et al. 2003; Bertoli-Avella et al. 2004; Pastor and Goate 2004). Other APP and PS tg models have been developed in rats, drosophila, and C. elegans, either using constitutively active or regulatable promoters, or viral vectors. The main focus of this review will be dedicated to murine APP tg models and the corresponding neurodegenerative pathology and alterations in neurogenesis, however, it is important to emphasize that this represents one aspect of the disease; other components, such as NFT pathology will be addressed by others.
Experimental APP transgenic murine models of Alzheimer's disease

In $\mathrm{AD}$, APP mutations as well as mutations in PS1 and 2 and polymorphisms in apolipoprotein E (ApoE) have also been linked with $\mathrm{AD}$ (Fig. 2) and as such are important targets. Most efforts toward developing tg models have been focused on overexpression of mutant APP (Table 1) in combination with mutant PS1. A summary of the FAD mutations reproduced in tg mouse models is presented in Fig. 3. Previously developed tg animal models have shown that it is possible to reproduce certain aspects of $\mathrm{AD}$ pathology over a shorter period of time (Masliah et al. 1996; Games et al. 1997; Price et al. 2000). In this model, the platelet-derived growth factor ( $\beta$ chain) (PDGF- $\beta$ ) promoter drives an alternatively spliced human APP (hAPP) minigene (PDAPP) encoding mutated (Indiana, V717F) hAPP695, 751, and 770 (Games et al. 1995; Rockenstein et al. 1995). This confers a high ratio of mRNA encoding mutated hAPP versus wild-type mouse APP (Rockenstein et al. 1995), which promotes development of typical amyloid plaques, dystrophic neurites, loss of presynaptic terminals, astrocytosis and microgliosis (Games et al. 1995, 1997; Masliah et al. 1996).

Other models have expressed mutant hAPP under the regulatory control of either the human or murine (m)Thy 1 promoter (Andra et al. 1996; Sturchler-Pierrat et al. 1997; Moechars et al. 1999; Bornemann and Staufenbiel 2000) or the prion protein ( $\mathrm{PrP}$ ) promoter (Hsiao et al. 1996; Borchelt et al. 1997). Amyloid deposition begins at 12 months of age; however, co-expression of mutant PS1 accelerates amyloid deposition, beginning at 4 months of age (Borchelt et al. 1996, 1997; Holcomb et al. 1998). Another previously developed model, where hAPP is also expressed under the control of the PrP promoter, displays even earlier onset of amyloid deposition, starting at 3 months and progressing to mature plaques and neuritic pathology from 5 months of age, accompanied by high levels of $\mathrm{A} \beta_{1-42}$ (Chishti et al. 2001). While the PrP promoter has provided several models that mimic aspects of FAD, other promoters targeting expression of APP to neurons provide alternative models demonstrating pathology that recapitulate similar and additional aspects of FAD. In this regard, we have generated lines of tg mice expressing hAPP751 cDNA containing the London (Lon, V717I) and Swedish (Swe, K670N/M671L) mutations under the regulatory control of the mThy1 gene (mThy1hAPP751) (Rockenstein et al. 2001; Fig. 4). While expression of mutant hAPP under the PDGF- $\beta$ promoter results in the production of diffuse (and some mature) plaques (Games et al. 1995; Mucke et al. 2000), tg expression of mutant hAPP under the mThy1 (Andra et al. 1996) and PrP (Hsiao et al. 1996; Borchelt et al. 1997) 


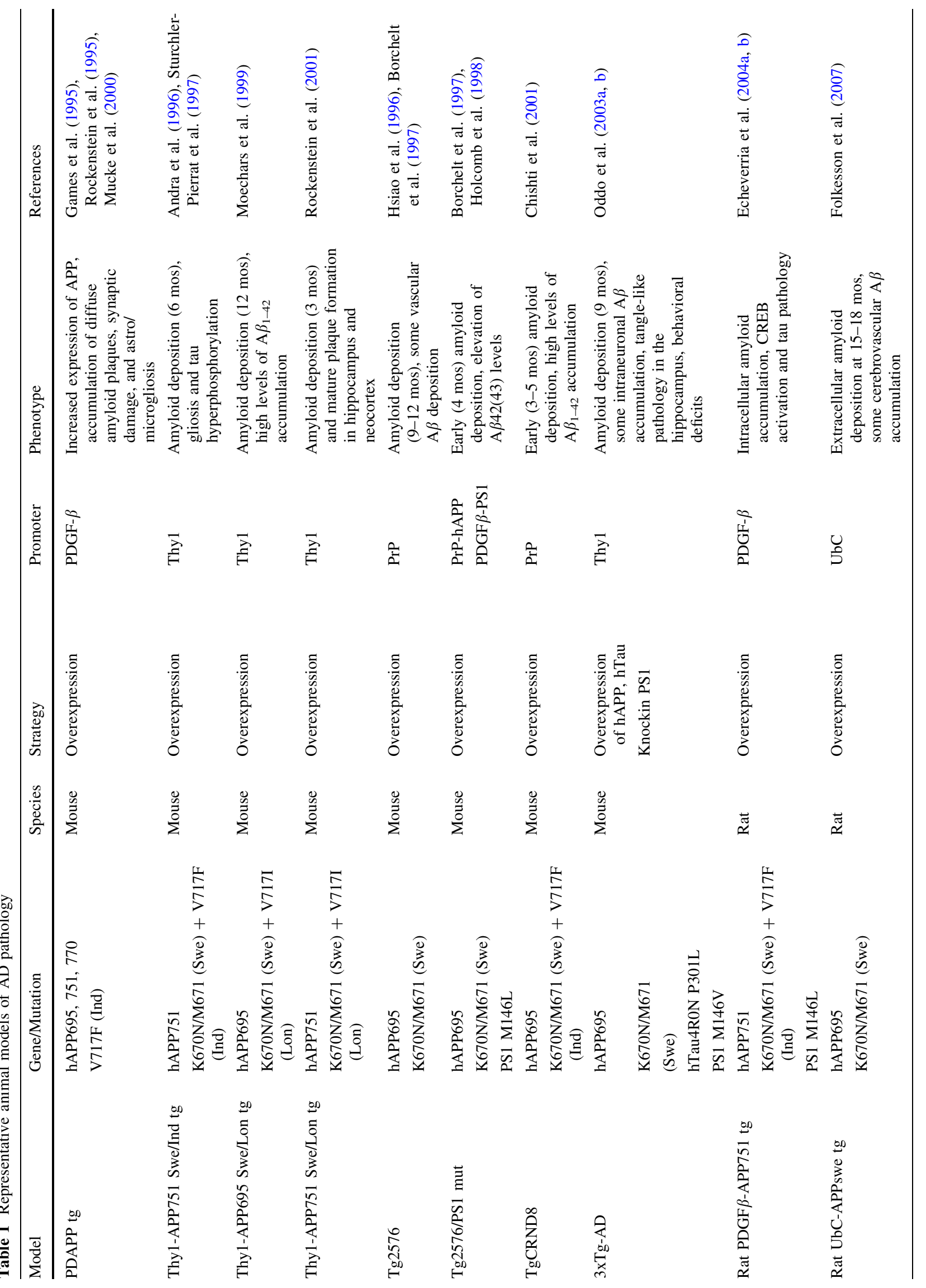




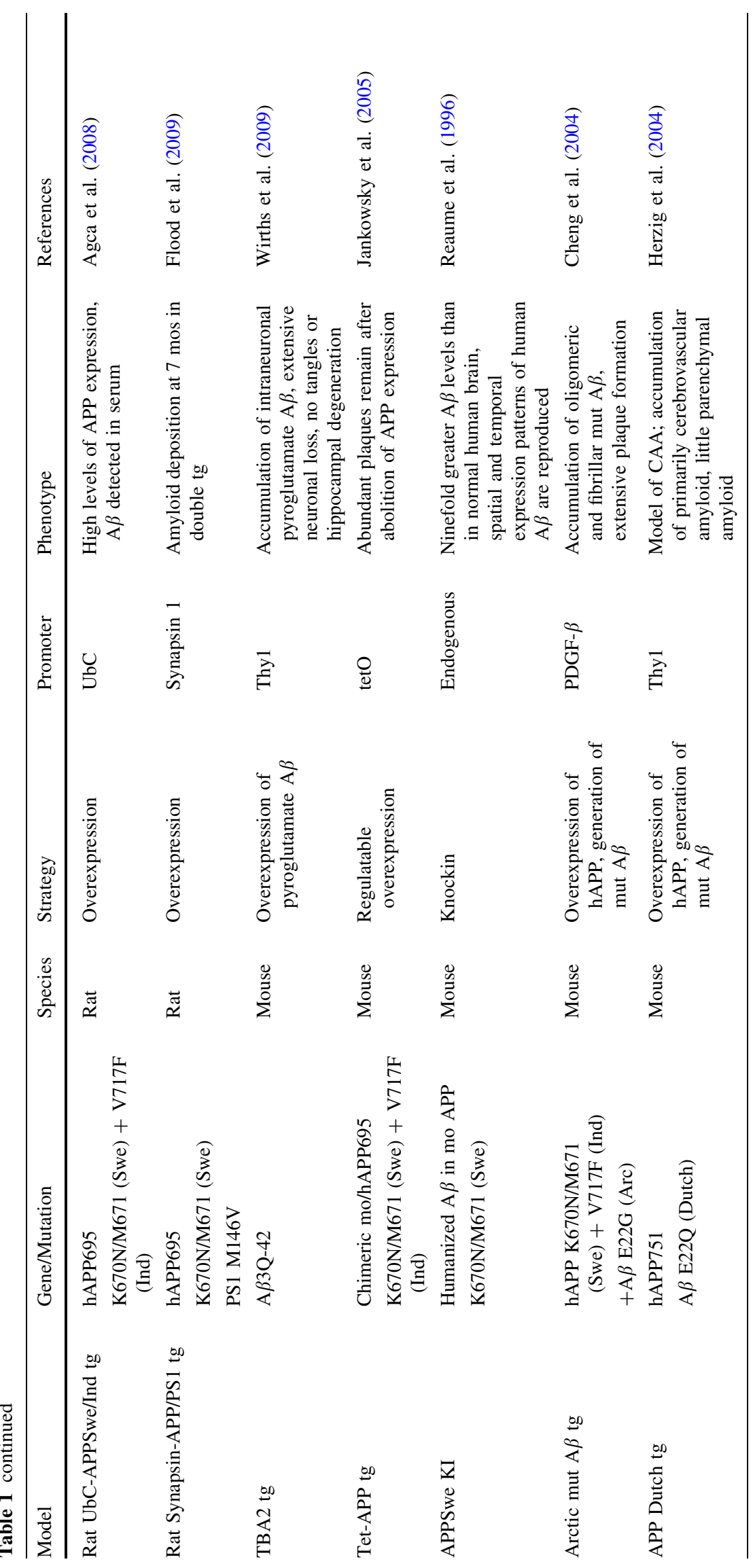


Fig. 3 Diagram showing common mutations in the APP gene that are utilized in the generation of animal models of AD. Mutations in the N- and C-terminal domains of APP result in the accumulation of intracellular and/or extracellular $\mathrm{A} \beta$ species, while mutations in the $\mathrm{A} \beta$ region lead to the development of amyloid angiopathy. Swe Swedish mutation, Lon London mutation, Ind Indiana mutation, Arc Arctic mutation, $T M$ transmembrane domain

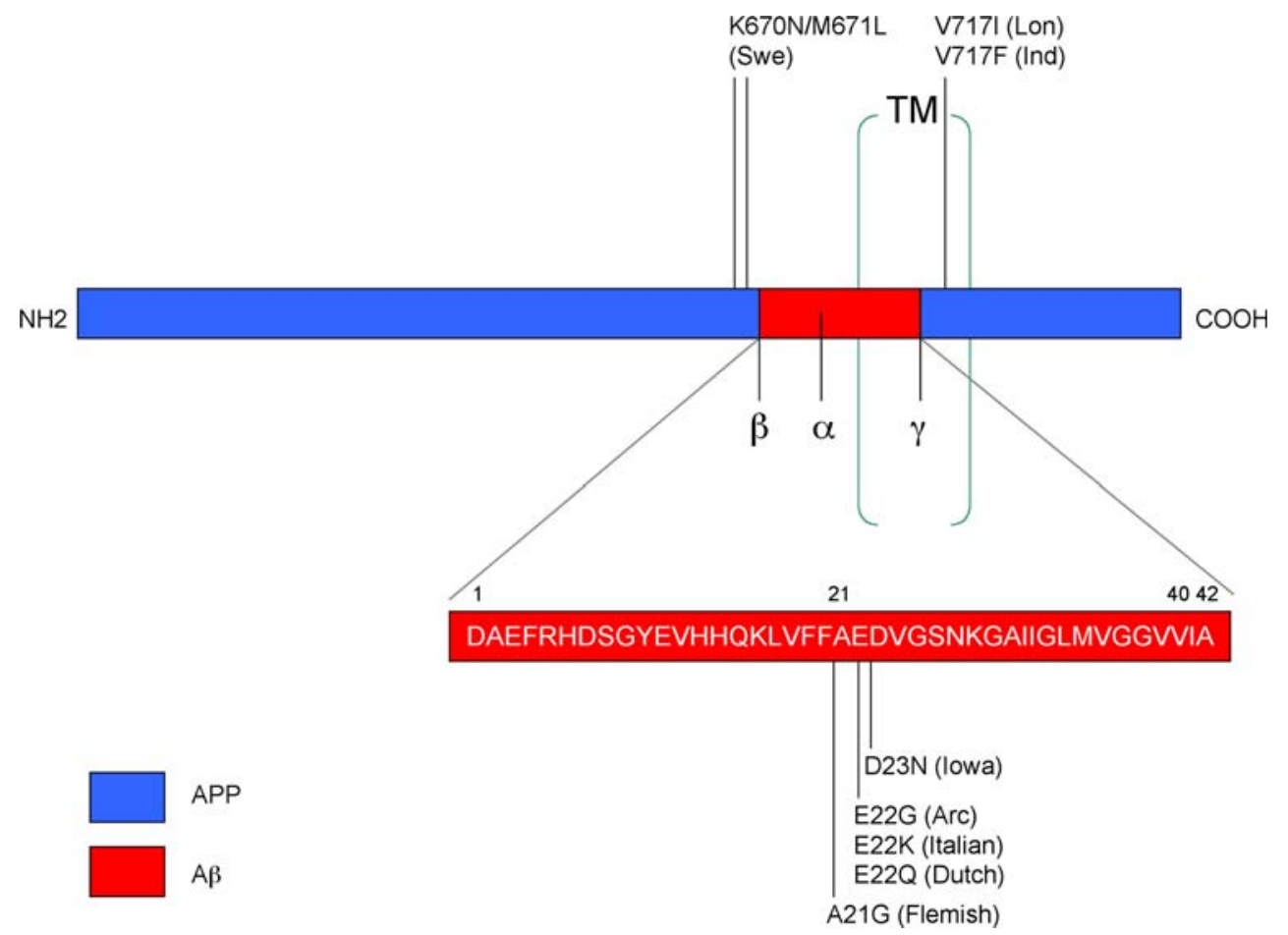

promoters favors the formation of mature plaques in the hippocampus and neocortex. This suggests that the differential patterns of $\mathrm{A} \beta$ deposition might be dependent on the specific neuronal populations selected by the promoter, levels of expression and topographical distribution of the transgene, and levels of $\mathrm{A} \beta_{1-40}$ and $\mathrm{A} \beta_{1-42}$. Consistent with this, in FAD and Down syndrome, production of high levels of $\mathrm{A} \beta_{1-42}$ results in early plaque formation (Citron et al. 1997). This suggests that early age of onset and plaque formation depends on high levels of $\mathrm{A} \beta_{1-42}$ production (Rockenstein et al. 2001). Finally, of considerable interest and wide attention is the triple tg mouse model developed by LaFerla et al. (2007) (3xTg-AD) that involves overexpression of mutant APP (Swe) and Tau (P301L) under the Thy1.2 promoter in homozygous mutant PS1 (M146V) knockin mice. These mice develop neurological deficits, amyloid deposition, and tangle-like pathology in the hippocampus (Oddo et al. 2003a, b).

Models with accumulation of intracellular $\mathrm{A} \beta$ have also been developed. Among the most interesting ones is a rat tg model that expresses Swe/Ind mutant hAPP751 (K670N/ M671L, V717F) alone or with mutant PS1 (M146L) under the control of the PDGF- $\beta$ promoter (Echeverria et al. 2004a, b). These animals are characterized by extensive intracellular amyloid accumulation, CREB activation, and tau pathology (Echeverria et al. 2004a, b). Other APP tg rat models express mutant hAPP695 (K670N/M671L) under the control of the ubiquitin-C (UbC) promoter, which shows a similar ubiquitous expression pattern as the human APP promoter (Folkesson et al. 2007); (Agca et al. 2008).
These animals have been shown to develop extracellular amyloid deposits at 15-18 months. A third rat line carrying both mutant APP (K670N/M671L) and a human PS1 transgene with the FAD M146V mutation under the control of the rat synapsin 1 promoter develops plaques at 7 months of age (Flood et al. 2009). While these models show promising results recapitulating the intracellular accumulation of $\mathrm{A} \beta$ that is observed in $\mathrm{AD}$ patients, more detailed neuropathological examination is necessary to fully characterize these models. Interestingly, the $3 \mathrm{xTg}-\mathrm{AD}$ model described earlier has also been shown to accumulate intraneuronal $\mathrm{A} \beta$, and more recent studies have focused on this as a mouse model of intracellular $\mathrm{A} \beta$ deposition. In these animals, accumulation of intraneuronal $\mathrm{A} \beta$ leads to progressive degeneration and death of neurons in the brains of $\operatorname{tg}$ mice (LaFerla et al. 2007).

Remarkably, post-transcriptionally modified $\mathrm{A} \beta$ also accumulates in substantial quantities intraneuronally (Fig. 5). In particular, pyroglutamate $\mathrm{A} \beta_{3-42}$ triggers a lethal phenotype with neurodegeneration in a mouse model that expresses $A \beta_{3-42}$ peptides under the control of the Thy 1 promoter (TBA2 tg) (Wirths et al. 2009). This model expresses $\mathrm{A} \beta$ with $\mathrm{N}$-terminal glutamine (A $\beta 3 \mathrm{Q}-42)$ as a fusion protein with the murine thyrotropin-releasing hormone $(\mathrm{mTRH})$, for transport via the secretory pathway (Cynis et al. 2006). The levels of converted A $\beta$ (3(pE)-42) in TBA2 mice are comparable to the APP/PS1 knockin mouse model (Casas et al. 2004), with extensive neuron loss and associated behavioral deficits (Wirths et al. 2009). Eight weeks after birth, TBA2 mice develop neurological 
A

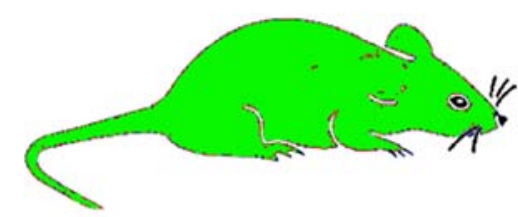

mThy-1 gene APP 751 mut

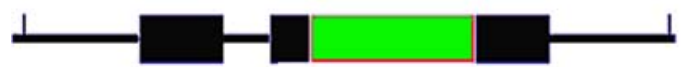

C

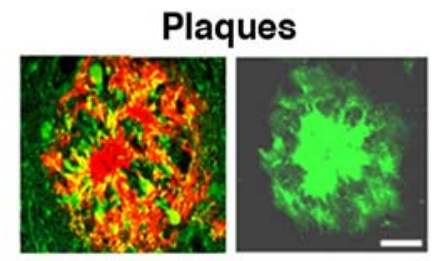

E

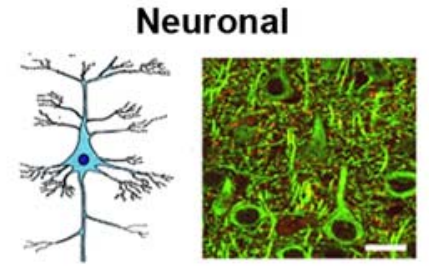

Fig. 4 Characterization of cognitive and neuropathological alterations in the brains of mThy1-hAPP tg mice. a Structure of mutant hAPP transgene under the control of the mThy-1 promoter. b Memory portion of the water maze behavioral test where the platform was removed (Probe test) to evaluate the number of entrances into the target quadrant where the platform was previously located (\# Entrances), the number of times the animal passed over the location, where the platform was (\# Passes), and time spent (Time) swimming in the target quadrant where the platform was previously located. APP tg mice exhibited reduced performance compared to

impairments together with abundant loss of Purkinje cells (Wirths et al. 2009). Although the TBA2 model lacks important AD-typical neuropathological features like tangles and hippocampal degeneration, it clearly demonstrates that intraneuronal $\mathrm{A} \beta(3(\mathrm{pE})-42)$ is neurotoxic in vivo (Wirths et al. 2009).

To further understand the mechanisms involved in $\mathrm{A} \beta$ deposition and clearance, a unique model of neuronal APP expression has been developed that expresses mutant (Swe/ Ind) hAPP695 under the control of a tetracycline-sensitive promoter (Jankowsky et al. 2005). This approach allows the instantaneous abolition (95\%) of hAPP expression upon treatment with doxycycline. Animals were treated with antibiotic after plaques were already formed and in this model, very little new hAPP — and subsequently, A $\beta$-is produced after antibiotic treatment, so the natural rate of A $\beta$ clearance can be assessed. Notably, even after 12 months of suppression of APP production, amyloid

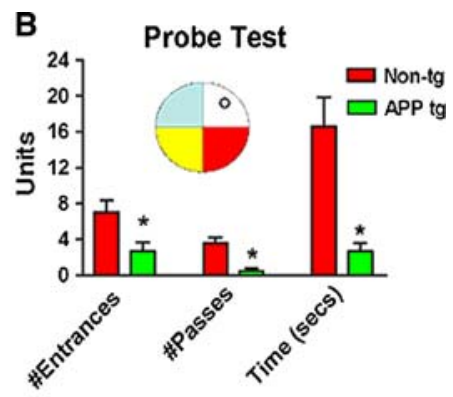

D Synaptophysin

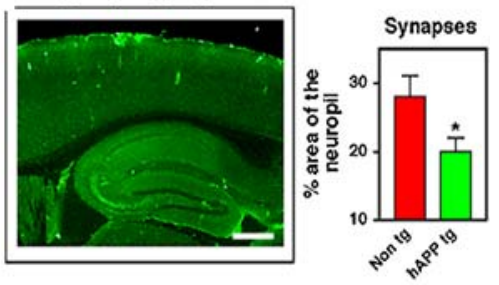

F hAPP-IR Dentate gyrus

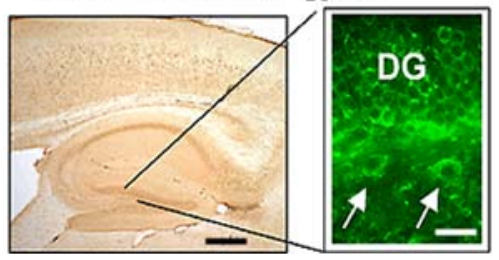

non-tg controls in all three measures of memory retention in this behavioral test. c $\mathrm{A} \beta$-immunoreactive deposits in the cortex of an APP tg mouse. Scale bar $50 \mu \mathrm{m}$. d Reduced synaptophysin immunoreactivity in the brain of an APP tg mouse. Scale bar $0.2 \mathrm{~mm}$. e Degeneration of the MAP2-immunoreactive dendritic arbor in the cortex of an APP tg mouse. Scale bar $10 \mu \mathrm{m}$. f hAPP immunoreactivity in the dentate gyrus (DG) of an APP tg mouse. Scale bar $1 \mathrm{~mm}$ (left panel), $20 \mu \mathrm{m}$ (right panel). * $p<0.05$ compared to non-tg controls by Student's $t$-test $(n=4$ mice per group)

deposits in the brains of treated mice remained abundant (Jankowsky et al. 2005). This indicates that, once formed, amyloid plaques are highly resistant to dissolution in the brain, and further suggests that therapeutic approaches based solely on reducing amyloid production may not be effective, and may need to be combined with clearancebased treatments.

While most animal models of $\mathrm{AD}$ involve ectopic expression or overexpression of FAD-related genes, some pathological features of $\mathrm{AD}$ have been recapitulated in mutant and knockin animals in which FAD-causing mutations are targeted into their endogenous genes. One advantage to gene-targeted and knockin models is that developmental and tissue-specific expression patterns of human $\mathrm{A} \beta$ are relatively preserved because the gene encoding the mutant precursor protein remains in its normal chromosomal location. One of the first models to express mutant APP in its endogenous location in the 
Fig. 5 Increased intracellular pyroglutamate-A $\beta$ immunoreactivity and synaptic deterioration in mThy1-hAPP tg mice. a-c Sections from the brains of non-tg and APP tg mice were immunolabeled with an antibody against pyroglutamate $\mathrm{A} \beta_{3-42}$ and developed with $\mathrm{DAB}$. Increased intraneuronal immunoreactivity was detected in the cortex of APP tg mice compared to non-tg controls. Scale bar $20 \mu \mathrm{m}$. d-f Reduced synaptophysin (SY38) immunoreactivity in the neuropil of APP $\operatorname{tg}$ mice compared to non-tg controls. Scale bar $20 \mu \mathrm{m} .{ }^{*} p<0.05$ compared to non-tg controls by Student's $t$-test $(n=4$ mice per group)

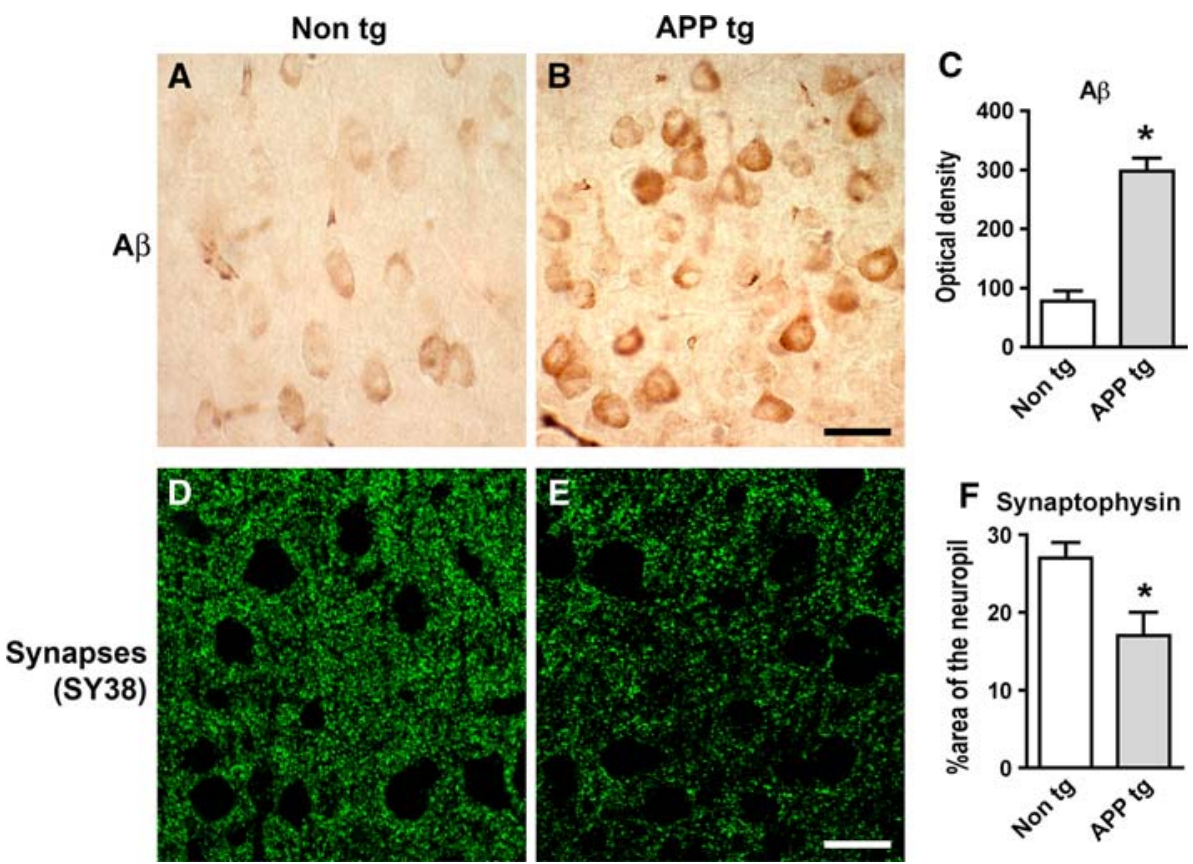

mouse genome used site-specific mutagenesis to transform murine APP into "humanized" APP bearing the Swe mutation (K670N/M671L) (Reaume et al. 1996). In this model, amyloidogenic processing was somewhat enhanced and measurable increases in $\mathrm{A} \beta$ production were detected (Siman et al. 2000), however, the effects were not as robust as in APP $\operatorname{tg}$ models. Interestingly, in the gene-targeted mutant APP animals, the pathological process is markedly enhanced upon introduction of a PS1 P264L knockin mutation in these mutant APP animals, characterized by a large increase in $\mathrm{A} \beta_{1-42}$ levels and an acceleration of agedependent onset of amyloid pathology (Siman et al. 2000).

It is still controversial which $\mathrm{A} \beta$ species is responsible for the neurodegenerative process in $\mathrm{AD}$. While most recent studies support a role for small oligomers (dimers, trimers, up to dodecamers) (Walsh and Selkoe 2004; Glabe 2005; Glabe and Kayed 2006), others emphasize an important role for the accumulation of intracellular $\mathrm{A} \beta$ and for post-transcriptional modifications, such as pyroglutamate changes (Cynis et al. 2008; Schilling et al. 2008). Models reproducing the formation of $\mathrm{A} \beta$ oligomers include those expressing APP bearing the Arctic mutation (E22G) under the control of the PDGF- $\beta$ promoter (Cheng et al. 2004). This mutation is highly fibrillogenic in vivo, and these mice rapidly develop extensive plaque formation (Cheng et al. 2004). Mutations that increase oligomers and protofibril formation include the E22G (Arctic), E22K (Italian), E22Q (Dutch), and the D23N (Iowa) amino acid substitutions (Demeester et al. 2001; Lashuel et al. 2003; Betts et al. 2008; Fig. 3). Interestingly, all of these mutations are located within the $\mathrm{A} \beta$-containing sequence of APP, and in addition to the apparent oligomer-promoting effect of these mutations, it has been proposed that the pathogenic effect may also be related to a resistance in proteolysis of $\mathrm{A} \beta$ (Tsubuki et al. 2003). In support of this possibility, another familial APP mutation, A21G (Flemish), exhibits a significantly reduced rate of proteolysis by the A $\beta$-degrading enzyme Neprilysin (Betts et al. 2008).

Most emphasis has been placed on the amyloid deposition in the intracellular compartment and in the plaques. However, patients with AD also develop amyloid deposition around blood vessels, a process that ultimately leads to a condition known as cerebral amyloid angiopathy (CAA). This can cause vascular fragility and hemorrhages (reviewed in Pezzini et al. (2009)), and it is important to note that therapeutic anti-A $\beta$ vaccination strategies may increase susceptibility to developing CAA (Boche et al. 2008). Patients who have hereditary cerebral hemorrhage with amyloidosis-Dutch type (HCHWA-D) generate both wild-type $\mathrm{A} \beta$ and E22Q-mutant $\mathrm{A} \beta$ (A $\beta$ Dutch) (van Duinen et al. 1987; Levy et al. 1990). The brains of patients with HCHWA-D show CAA with very little parenchymal amyloid deposition (Herzig et al. 2006). To date, there are several mouse models that deposit amyloid in the blood vessels, including some models more widely used to study parenchymal $\mathrm{A} \beta$ accumulation, such as the Tg2576 mouse (Hsiao et al. 1996; Frackowiak et al. 2003). The only mouse model that develops significant cerebrovascular amyloid with virtually no parenchymal amyloid is the APPDutch mouse, which overexpresses hAPP751 bearing the E693Q (E22Q in $\mathrm{A} \beta$ ) mutation under the control of the Thy1 promoter (Herzig et al. 2004). More recently, the same group has also developed a new model of CAA by crossing the APPDutch mutant mice with 
APP23 mice that express mutant hAPP751 (Swe) under the control of the Thy1 promoter (Herzig et al. 2009). While the classical APP23 mice display extracellular A $\beta$ plaques, double-tg APP23/APPDutch mice co-deposited A $\beta$ Dutch (mainly $\mathrm{A} \beta$ Dutch1-40) and wild-type $\mathrm{A} \beta$ at twofold levels in the vasculature, with reduced parenchymal deposition (Herzig et al. 2009). Hemorrhages were also significantly increased in the double-tg mice. These studies suggest that A $\beta$ Dutch1-40 increases vascular deposits and reduces parenchymal amyloidosis similar to HCHWA-D patients.

For a comprehensive review of these and additional $\mathrm{tg}$ models of neurodegenerative disease, please visit the Alzheimer's forum website at: http://www.alzforum.org/ res/com/tra.

\section{Alterations in APP processing, synaptic plasticity, and neurogenesis in APP tg models}

The most significant correlate to the severity of the cognitive impairment in $\mathrm{AD}$ is the loss of synapses in the frontal cortex and limbic system (DeKosky and Scheff 1990; Terry et al. 1991; Masliah and Terry 1994; DeKosky et al. 1996; Figs. 2, 4). The pathogenic process in AD involves alterations in synaptic plasticity that include changes in formation of synaptic contacts, changes in spine morphology, and abnormal area of synaptic contact (Scheff and Price 2003). However, other cellular mechanisms necessary to maintain synaptic plasticity might also be affected in AD (Cotman et al. 1993; Masliah 2000; Masliah et al. 2001). Recent studies indicate that neurogenesis in the mature brain plays an important role maintaining synaptic plasticity and memory formation in the hippocampus (van Praag et al. 2002). In the adult nervous system, motor activity and environmental enrichment (EE) have been shown to stimulate neurogenesis in the hippocampal dentate gyrus (DG) (Gage et al. 1998; van Praag et al. 2002). Physiological neurogenesis in the adult brain is regulated by numerous cell extrinsic and intrinsic factors, including local cytokine/chemokine signals and intracellular signal transduction (Johnson et al. 2009). In this context, recent studies have shown that, among other pathways, the Notch (Breunig et al. 2007; Crews et al. 2008), cyclin-dependent kinase-5 (CDK5) (Jessberger et al. 2008; Lagace et al. 2008), and wnt/bone morphogenetic protein (BMP) (Lim et al. 2000; Lie et al. 2005) cascades are involved in regulating adult neurogenesis. Interestingly, studies of human brains (Tatebayashi et al. 2003) and tg animal models have demonstrated significant alterations in the process of adult neurogenesis in the hippocampus in AD (Dong et al. 2004; Jin et al. 2004; Wen et al. 2004; Chevallier et al. 2005; Donovan et al. 2006). The deficient neurogenesis in the subgranular zone
(SGZ) of the DG found in our APP tg mice (Rockenstein et al. 2007; Fig. 6) is consistent with studies of other lines of APP $\mathrm{tg}$ mice and other models of AD that have shown decreased markers of neurogenesis, such as bromodeoxyuridine $(\mathrm{BrdU})+$, and doublecortin $(\mathrm{DCX})+$ cells, with an increase in the expression of markers of apoptosis (Feng et al. 2001; Haughey et al. 2002; Dong et al. 2004; Wang et al. 2004).

A different study reported increased neurogenesis in the PDAPP model (Jin et al. 2004). Another recent study showed that in 5-month-old APP23 tg mice prior to amyloid deposition, there was no robust difference in neurogenesis relative to wild-type control mice, but 25-month-old amyloid-depositing APP23 mice showed significant increases in neurogenesis compared to controls (Ermini et al. 2008). In contrast, 8-month-old amyloiddepositing APP/PS1 tg mice revealed decreases in neurogenesis compared to controls. Furthermore, 8-month-old nestin-GFP $\times$ APP/PS1 mice exhibited decreases in quiescent nestin-positive astrocyte-like stem cells, while transient amplifying progenitor cells did not change in number (Ermini et al. 2008). Strikingly, both astrocyte-like and transient-amplifying progenitor cells revealed an aberrant morphologic reaction toward congophilic amyloid deposits. A similar reaction toward the amyloid was no longer observed in doublecortin-positive immature neurons (Ermini et al. 2008). These results provide evidence for a disruption to neuronal progenitor cells (NPCs) in an amyloidogenic environment and support findings that neurogenesis is differentially affected among various tg mouse models of $\mathrm{AD}$, probably due to variations in promoter cell type specificity, expression levels, and other factors. A more comprehensive analysis of neurogenesis in APP $\mathrm{tg}$ mice showed that while in the molecular layer (ML) of the DG there is an increased number of NPC, in the SGZ markers of neurogenesis are decreased, indicating that in PDAPP animals there is altered migration and increased apoptosis of NPC that contributes to the deficits in neurogenesis (Donovan et al. 2006).

The molecular mechanisms of aberrant neurogenesis in $\mathrm{AD}$ are unclear, however, several signaling pathways that control physiological adult neurogenesis are known to be dysregulated in AD. For example, CDK5 is hyperactivated in $\mathrm{AD}$ by $\mathrm{A} \beta$ peptide-mediated calcium influx (Lee et al. 2000). In mature neurons, this contributes to neurodegeneration by promoting aberrant phosphorylation of downstream targets of CDK5 such as tau (Ahlijanian et al. 2000), however, the direct effects on NPCs are unknown. It is possible that kinases, such as CDK5 that are disturbed in mature neurons in AD may also play a role in the mechanisms of disrupted neurogenesis in the adult AD brain.

While a considerable body of work is currently emerging on neurogenic alterations associated with the pathogenesis 
Fig. 6 Reduced markers of neurogenesis and increased apoptosis in the hippocampus of APP tg mice. a-c Reduced BrdU immunoreactivity in the hippocampal dentate gyrus of APP tg mice treated with BrdU compared to non-tg controls treated with BrdU. d-e Reduced doublecortin (DCX) immunoreactivity in the hippocampal dentate gyrus of APP tg mice compared to non-tg controls. g-i Reduced proliferating cell nuclear antigen (PCNA)

immunoreactivity in the hippocampal dentate gyrus of APP tg mice compared to non-tg controls. $\mathbf{j}-\mathbf{l}$ Increased TUNEL-positive cells in the hippocampal dentate gyrus of APP tg mice compared to nontg controls. Scale bar $50 \mu \mathrm{m}$ for all panels. ${ }^{*} p<0.05$ compared to non-tg controls by Student's $t$-test ( $n=4$ mice per group)
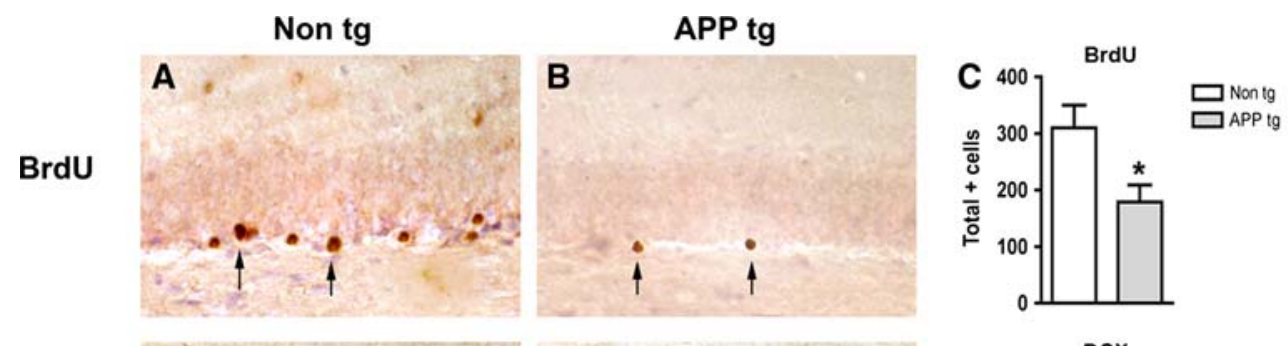

DCX
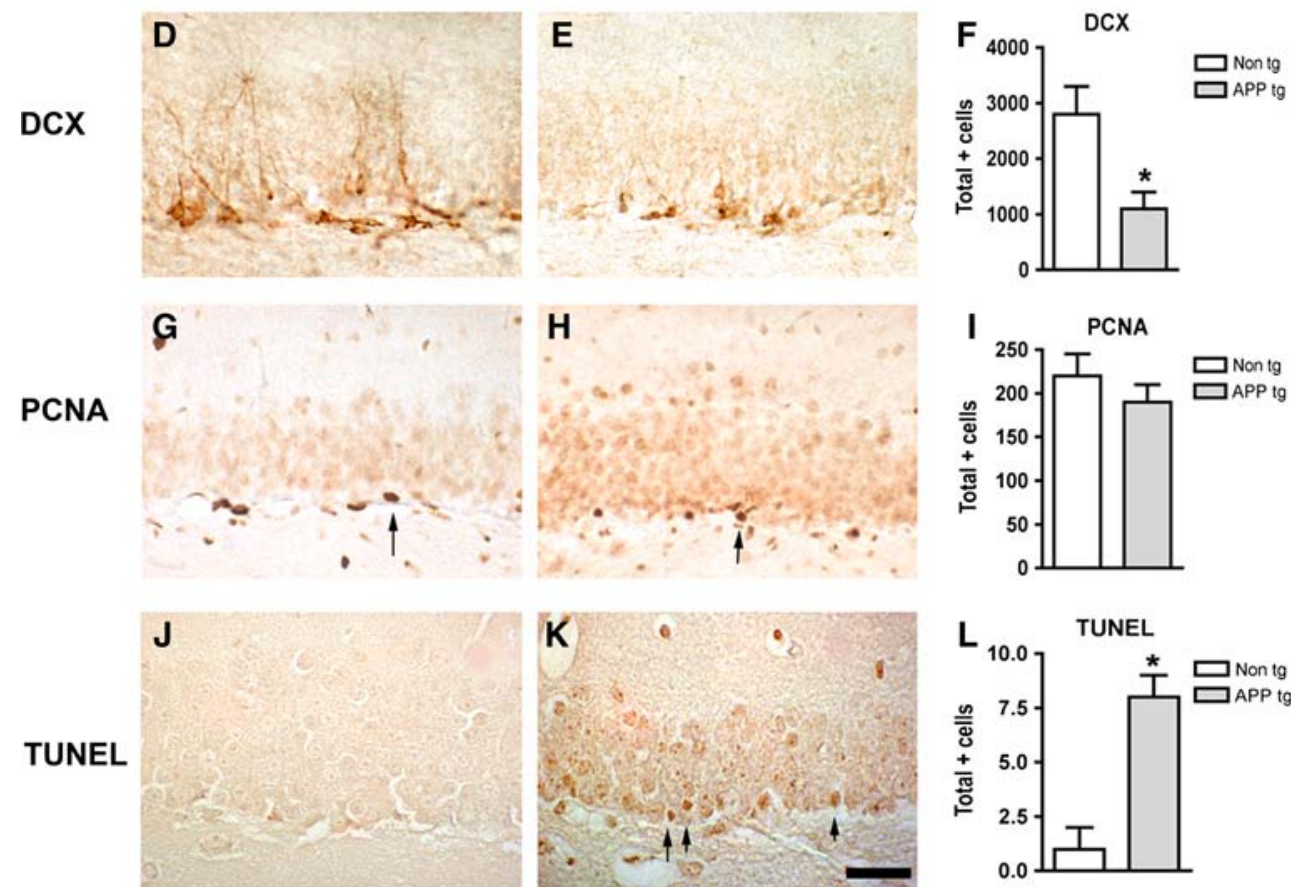

of $\mathrm{AD}$, it is important to keep the role of neurogenesis in perspective given the relatively limited number of brain regions that are neurogenic. It is an exciting prospect that new neurons from progenitor cells in the hippocampus could replace cells damaged during the pathogenesis of AD. However, the extent to which progenitor cells might integrate into already-established neural circuitry is unclear, and the problem of re-establishing long inter-regional connections is considerable. Furthermore, taking into account the distribution of AD pathology among various non-neurogenic brain regions, such as the entorhinal cortex and neocortex, it is possible that neurogenesis may not be an ideal target for repairing global neuronal damage in the brain. However, given the critical role of the hippocampus in the processes of learning and memory, and the recent studies showing that neurogenesis plays an important part in these functions (van Praag et al. 2002), it is possible that modulation of neurogenesis in this area might have therapeutic potential. Moreover, it is important to consider the interconnected circuitry that characterizes the brain's architecture. Although AD pathology in the hippocampus primarily affects the non-neurogenic pyramidal cell layers, the granular cells extend processes into the pyramidal layers, and additionally affect the connectivity of the entorhinal cortex via the perforant pathway. Taken together, much further work will be necessary to fully understand the role of neurogenesis in the pathogenesis of $\mathrm{AD}$ and the therapeutic potential of harnessing the regenerative capacity of progenitor cells.

Alterations in synaptic plasticity in AD might involve not only direct damage to the synapses but also interference with adult neurogenesis (Fig. 2). The mechanisms of synaptic pathology in $\mathrm{AD}$ are the subject of intense investigation. Studies of experimental models of $\mathrm{AD}$ and in human brain support the notion that aggregation of $\mathrm{A} \beta$, resulting in the formation of toxic oligomers rather than fibrils, might be ultimately responsible for the synaptic damage that leads to cognitive dysfunction in patients with AD (Walsh and Selkoe 2004; Glabe 2005; Glabe and Kayed 2006; Fig. 1). Supporting this notion, it has been shown that $\mathrm{A} \beta$ oligomers reduce synaptic transmission and dendritic spine movement (Lacor et al. 2004; Moolman et al. 2004; Walsh and Selkoe 2004), and interfere with axoplasmic flow and activate signaling pathways that might lead to synaptic dysfunction, tau hyperphosphorylation, and cell death. Moreover, a dodecameric $\mathrm{A} \beta$ complex denominated $* 56$ has been recently characterized (Lesne et al. 2006) in brains from APP tg mice and shown 
to contribute to the behavioral alterations in these animals. The differential effects of this and other toxic oligomeric species of $\mathrm{A} \beta$ in mature and developing neurons and synapses awaits further investigation.

The accumulation of $\mathrm{A} \beta$ in the CNS and the formation of toxic oligomers most likely depend on the rate of $\mathrm{A} \beta$ aggregation, synthesis, and clearance (Fig. 7). Although most effort has been concentrated at elucidating the mechanisms of $\mathrm{A} \beta$ production and aggregation (Luo et al. 1999; Sinha et al. 1999; Vassar et al. 1999; Selkoe 2000; Cai et al. 2001), less is known about the mechanisms of $\mathrm{A} \beta$ clearance. As previously discussed in the section on $\operatorname{tg}$ models, the conditional APP tg model showed that enhancing clearance of $\mathrm{A} \beta$ may actually be more critical than preventing its production when considering potential therapies. This is also important because while most familial forms of $\mathrm{AD}$ might result from mutations that affect the rate of $\mathrm{A} \beta$ synthesis and aggregation, sporadic $\mathrm{AD}$ might be the result of alterations in $\mathrm{A} \beta$ clearance (Fig. 7). Pathways involved in $\mathrm{A} \beta$ clearance include LDLR-related protein (LRP) ligands, such as apolipoprotein E (ApoE) (Holtzman et al. 1995, 1999), lysosomal degradation (Nixon et al. 1992, 2005) and cleavage by proteolytic enzymes, such as Neprilysin, insulin-degrading enzyme (IDE), endothelin-converting enzyme (ECE), angiotensin converting enzyme (ACE), and matrix metalloproteinase-9 (MMP9) (Iwata et al. 2000, 2001; Selkoe 2001; Carson and Turner 2002; Leissring et al. 2003; Marr et al. 2004; Eckman and Eckman 2005; Saito et al. 2005; Fig. 7).

\section{Functional correlations to the structural pathology in APP tg mice}

The relationship among the patterns of $\mathrm{A} \beta$ production, amyloid deposition, neurodegeneration, and behavioral deficits in the $\operatorname{tg}$ models of $\mathrm{AD}$ is complex. One important finding common to several of these APP tg models is that there is no obvious neuronal dropout in early stages of pathogenesis (Irizarry et al. 1997a, b). In fact, the earliest

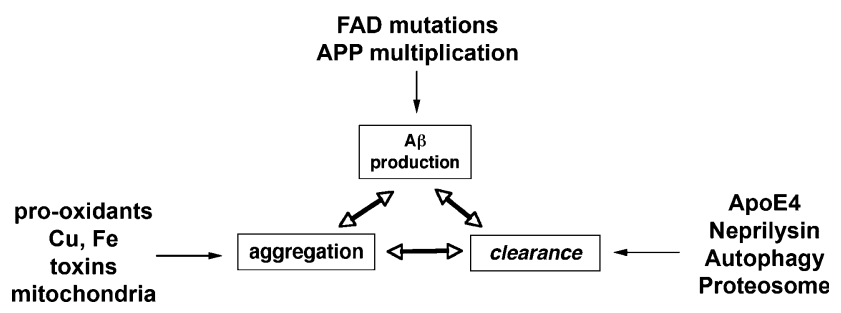

Fig. 7 Schematic diagram showing several factors involved in the regulation of $\mathrm{A} \beta$ accumulation into oligomers, including production, aggregation, and clearance neuronal pathology before amyloid deposition is the loss of synapses and dendrites in the limbic system and neocortex (Hsia et al. 1999; Mucke et al. 2000). This is accompanied by neurophysiological deficits and alterations in long-term potentiation (LTP) and field potential (Chapman et al. 1999; Hsia et al. 1999). Since the synaptic damage in these mice correlates better with the levels of soluble $\mathrm{A} \beta_{1-42}$ than with plaques, it has been proposed that neurodegeneration might be associated more with the neurotoxic effects of $\mathrm{A} \beta$ oligomers than with fibrillar amyloid (Mucke et al. 2000). In agreement with this possibility, studies of brain slices have shown that $\mathrm{A} \beta$ oligomers rather than fibrillar amyloid are toxic to synapses and depress LTP, leading to cognitive impairment (Walsh et al. 2002).

Other recently developed models have also focused on defining the effects of APP and its products on functional markers, including behavioral performance and LTP. These studies have shown that overexpression of the C-terminal APP fragment C100 under the control of neurofilament (NF) promoter results in amyloid-like production and electrophysiological alterations (Nalbantoglu et al. 1997). Although these, as well as the other APP tg animal models, have been shown to be of significant interest, the basic principle for their success rests in the ability to overexpress high levels of mutant APP, which is in a way rather non-physiological event. With the exception of Down syndrome, in sporadic AD there is no evidence for upregulation of APP expression but rather a shift in the ratio between APP770 and 751 to APP695. In this regard, a previous study (van Leeuwen et al. 1998) has shown frame shift mutations in APP and ubiquitin genes are present in some AD patients. It is conceivable that future tg models might utilize this mechanism in an attempt to reflect the more common sporadic forms of the disease.

\section{Conclusions}

In summary, a number of known mutations in the APP gene associated with familial forms of amyloid disorders have made it possible to recapitulate several features of amyloid pathology in the brains of $\mathrm{tg}$ animal models. While other genes, such as PS1 and tau have been manipulated alone or in combination with APP mutations, a large portion of the current literature describing the AD-like neurodegenerative phenotypes in animal models has been based on animal models expressing high levels of mutant APP. While APP $\operatorname{tg}$ murine models with mutations in the $\mathrm{N}$ - and $\mathrm{C}$-terminal flanking regions of $\mathrm{A} \beta$ are characterized by increased $\mathrm{A} \beta$ production with plaque formation, mutations in the midsegment of $\mathrm{A} \beta$ result in increased formation of oligomers, and mutations toward the C-terminus (E22Q) segment results in amyloid angiopathy. Several lines of evidence 
suggest that formation of $\mathrm{A} \beta$ oligomers reduces neuroplasticity and contributes to neuronal degeneration and alterations in neurogenesis. Specifically targeting these toxic oligomeric species of $\mathrm{A} \beta$ with $\beta$ - and $\gamma$-secretase inhibitors, immunization, and neurogenesis-stimulating therapies may provide individual or combination treatments that ameliorate multiple features of $\mathrm{AD}$ pathology.

Acknowledgments This work was supported by National Institutes of Health grants AG5131, AG11385, AG10435, NS44233 and AG18440.

Open Access This article is distributed under the terms of the Creative Commons Attribution Noncommercial License which permits any noncommercial use, distribution, and reproduction in any medium, provided the original author(s) and source are credited.

\section{References}

Agca C, Fritz JJ, Walker LC, Levey AI, Chan AW, Lah JJ, Agca Y (2008) Development of transgenic rats producing human betaamyloid precursor protein as a model for Alzheimer's disease: transgene and endogenous APP genes are regulated tissuespecifically. BMC Neurosci 9:28

Ahlijanian MK, Barrezueta NX, Williams RD, Jakowski A, Kowsz KP, McCarthy S, Coskran T, Carlo A, Seymour PA, Burkhardt JE, Nelson RB, McNeish JD (2000) Hyperphosphorylated tau and neurofilament and cytoskeletal disruptions in mice overexpressing human p25, an activator of cdk5. Proc Natl Acad Sci USA 97:2910-2915

Andra K, Abramowski D, Duke M, Probst A, Wiederholt K, Burki K, Goedert M, Sommer B, Staufenbiel M (1996) Expression of APP in transgenic mice: a comparison of neuron-specific promoters. Neurobiol Aging 17:183-190

Bertoli-Avella AM, Oostra BA, Heutink P (2004) Chasing genes in Alzheimer's and Parkinson's disease. Hum Genet 114:413-438

Betts V, Leissring MA, Dolios G, Wang R, Selkoe DJ, Walsh DM (2008) Aggregation and catabolism of disease-associated intraAbeta mutations: reduced proteolysis of AbetaA21G by neprilysin. Neurobiol Dis 31:442-450

Boche D, Zotova E, Weller RO, Love S, Neal JW, Pickering RM, Wilkinson D, Holmes C, Nicoll JA (2008) Consequence of Abeta immunization on the vasculature of human Alzheimer's disease brain. Brain 131:3299-3310

Borchelt D, Thinakaran G, Eckman C, Lee M, Davenport F, Ratovitsky T, Prada C, Kim G, Seekins S, Yager D (1996) Familial Alzheimer's disease-linked presenilin 1 variants elevate Ab1-42/1-40 ratio in vitro and in vivo. Neuron 17:1005-1013

Borchelt D, Ratovitski T, van Lare J, Lee M, Gonzales V, Jenkins N, Copeland N, Price D, Sisodia S (1997) Accelerated amyloid deposition in the brains of transgenic mice coexpressing mutant presenilin 1 and amyloid precursor proteins. Neuron 19:939-945

Bornemann KD, Staufenbiel M (2000) Transgenic mouse models of Alzheimer's disease. Ann N Y Acad Sci 908:260-266

Breunig JJ, Silbereis J, Vaccarino FM, Sestan N, Rakic P (2007) Notch regulates cell fate and dendrite morphology of newborn neurons in the postnatal dentate gyrus. Proc Natl Acad Sci USA 104:20558-20563

Cai H, Wang Y, McCarthy D, Wen H, Borchelt DR, Price DL, Wong PC (2001) BACE1 is the major beta-secretase for generation of Abeta peptides by neurons. Nat Neurosci 4:233-234
Carson JA, Turner AJ (2002) Beta-amyloid catabolism: roles for neprilysin (NEP) and other metallopeptidases? J Neurochem $81: 1-8$

Casas C, Sergeant N, Itier JM, Blanchard V, Wirths O, van der Kolk N, Vingtdeux V, van de Steeg E, Ret G, Canton T, Drobecq H, Clark A, Bonici B, Delacourte A, Benavides J, Schmitz C, Tremp G, Bayer TA, Benoit P, Pradier L (2004) Massive CA1/2 neuronal loss with intraneuronal and $\mathrm{N}$-terminal truncated Abeta42 accumulation in a novel Alzheimer transgenic model. Am J Pathol 165:1289-1300

Chapman PF, White GL, Jones MW, Cooper-Blacketer D, Marshall VJ, Irizarry M, Younkin L, Good MA, Bliss TV, Hyman BT, Younkin SG, Hsiao KK (1999) Impaired synaptic plasticity and learning in aged amyloid precursor protein transgenic mice. Nat Neurosci 2:271-276

Cheng IH, Palop JJ, Esposito LA, Bien-Ly N, Yan F, Mucke L (2004) Aggressive amyloidosis in mice expressing human amyloid peptides with the Arctic mutation. Nat Med 10:1190-1192

Chevallier NL, Soriano S, Kang DE, Masliah E, Hu G, Koo EH (2005) Perturbed neurogenesis in the adult hippocampus associated with presenilin-1 A246E mutation. Am J Pathol 167:151-159

Chishti MA, Yang DS, Janus C, Phinney AL, Horne P, Pearson J, Strome R, Zuker N, Loukides J, French J, Turner S, Lozza G, Grilli M, Kunicki S, Morissette C, Paquette J, Gervais F, Bergeron C, Fraser PE, Carlson GA, George-Hyslop PS, Westaway D (2001) Early-onset amyloid deposition and cognitive deficits in transgenic mice expressing a double mutant form of amyloid precursor protein 695. J Biol Chem 276:21562-21570

Citron M, Westaway D, Xia W, Carlson G, Diehl T, Levesque G, Johnson-Wood K, Lee M, Subert P, Davis A, Kholodenko D, Motter R, Sherrington R, Perry B, Hong Y, Strome R, Lieberburg I, Rommens J, Kim S, Schenk D, Fraser P, St. George Hyslop P, Selkoe D (1997) Mutant presenilins of Alzheimer's disease increase production of 42-residue amyloid beta-protein in both transfected cells and transgenic mice. Nature Med 3:67-72

Cotman C, Cummings B, Pike C (1993) Molecular cascades in adaptive versus pathological plasticity. In: Gorio A (ed) Neurodegeneration. Raven Press, New York, pp 217-240

Crews L, Mizuno H, Desplats P, Rockenstein E, Adame A, Patrick C, Winner B, Winkler J, Masliah E (2008) Alpha-synuclein alters Notch-1 expression and neurogenesis in mouse embryonic stem cells and in the hippocampus of transgenic mice. J Neurosci 28:4250-4260

Cruts M, Van Broeckhoven C (1998) Molecular genetics of Alzheimer's disease. Ann Med 30:560-565

Cuello AC (2005) Intracellular and extracellular Abeta, a tale of two neuropathologies. Brain Pathol 15:66-71

Cynis H, Schilling S, Bodnar M, Hoffmann T, Heiser U, Saido TC, Demuth HU (2006) Inhibition of glutaminyl cyclase alters pyroglutamate formation in mammalian cells. Biochim Biophys Acta 1764:1618-1625

Cynis H, Scheel E, Saido TC, Schilling S, Demuth HU (2008) Amyloidogenic processing of amyloid precursor protein: evidence of a pivotal role of glutaminyl cyclase in generation of pyroglutamate-modified amyloid-beta. Biochemistry 47:74057413

DeKosky S, Scheff S (1990) Synapse loss in frontal cortex biopsies in Alzheimer's disease: correlation with cognitive severity. Ann Neurol 27:457-464

DeKosky ST, Scheff SW, Styren SD (1996) Structural correlates of cognition in dementia: quantification and assessment of synapse change. Neurodegeneration 5:417-421

Demeester N, Mertens C, Caster H, Goethals M, Vandekerckhove J, Rosseneu M, Labeur C (2001) Comparison of the aggregation properties, secondary structure and apoptotic effects of wild- 
type, Flemish and Dutch N-terminally truncated amyloid beta peptides. Eur J Neurosci 13:2015-2024

Dickson D, Farlo J, Davies P, Crystal H, Fuld P, Yen S (1988) Alzheimer disease. A double immunohistochemical study of senile plaques. Am J Pathol 132:86-101

Dong H, Goico B, Martin M, Csernansky CA, Bertchume A, Csernansky JG (2004) Modulation of hippocampal cell proliferation, memory, and amyloid plaque deposition in APPsw (Tg2576) mutant mice by isolation stress. Neuroscience 127:601-609

Donovan MH, Yazdani U, Norris RD, Games D, German DC, Eisch AJ (2006) Decreased adult hippocampal neurogenesis in the PDAPP mouse model of Alzheimer's disease. J Comp Neurol 495:70-83

Echeverria V, Ducatenzeiler A, Alhonen L, Janne J, Grant SM, Wandosell F, Muro A, Baralle F, Li H, Duff K, Szyf M, Cuello AC (2004a) Rat transgenic models with a phenotype of intracellular Abeta accumulation in hippocampus and cortex. J Alzheimers Dis 6:209-219

Echeverria V, Ducatenzeiler A, Dowd E, Janne J, Grant SM, Szyf M, Wandosell F, Avila J, Grimm H, Dunnett SB, Hartmann T, Alhonen L, Cuello AC (2004b) Altered mitogen-activated protein kinase signaling, tau hyperphosphorylation and mild spatial learning dysfunction in transgenic rats expressing the beta-amyloid peptide intracellularly in hippocampal and cortical neurons. Neuroscience 129:583-592

Eckman EA, Eckman CB (2005) Abeta-degrading enzymes: modulators of Alzheimer's disease pathogenesis and targets for therapeutic intervention. Biochem Soc Trans 33:1101-1105

Ermini FV, Grathwohl S, Radde R, Yamaguchi M, Staufenbiel M, Palmer TD, Jucker M (2008) Neurogenesis and alterations of neural stem cells in mouse models of cerebral amyloidosis. Am J Pathol 172:1520-1528

Feng R, Rampon C, Tang YP, Shrom D, Jin J, Kyin M, Sopher B, Miller MW, Ware CB, Martin GM, Kim SH, Langdon RB, Sisodia SS, Tsien JZ (2001) Deficient neurogenesis in forebrainspecific presenilin-1 knockout mice is associated with reduced clearance of hippocampal memory traces. Neuron 32:911-926

Ferrigno P, Silver P (2000) Polyglutamine expansions: proteolysis, chaperones, and the dangers of promiscuity. Neuron 26:9-12

Flood DG, Lin YG, Lang DM, Trusko SP, Hirsch JD, Savage MJ, Scott RW, Howland DS (2009) A transgenic rat model of Alzheimer's disease with extracellular Abeta deposition. Neurobiol Aging 30:1078-1090

Folkesson R, Malkiewicz K, Kloskowska E, Nilsson T, Popova E, Bogdanovic N, Ganten U, Ganten D, Bader M, Winblad B, Benedikz E (2007) A transgenic rat expressing human APP with the Swedish Alzheimer's disease mutation. Biochem Biophys Res Commun 358:777-782

Frackowiak J, Miller DL, Potempska A, Sukontasup T, MazurKolecka B (2003) Secretion and accumulation of Abeta by brain vascular smooth muscle cells from AbetaPP-Swedish transgenic mice. J Neuropathol Exp Neurol 62:685-696

Gage FH, Kempermann G, Palmer TD, Peterson DA, Ray J (1998) Multipotent progenitor cells in the adult dentate gyrus. J Neurobiol 36:249-266

Games D, Adams D, Alessandrini R, Barbour R, Berthelette P, Blackwell C, Carr T, Clemes J, Donaldson T, Gillespie F, Guido T, Hagopian S, Johnson-Wood K, Khan K, Lee M, Leibowitz P, Lieberburg I, Little S, Masliah E, McConlogue L, MontoyaZavala M, Mucke L, Paganini L, Penniman E, Power M, Schenk D, Seubert P, Snyder B, Soriano F, Tan H, Vitale J, Wadsworth S, Wolozin B, Zhao J (1995) Alzheimer-type neuropathology in transgenic mice overexpressing $\mathrm{V} 717 \mathrm{~F}$ b-amyloid precursor protein. Nature 373:523-527
Games D, Masliah E, Lee M, Johnson-Wood K, Schenk D (1997) Neurodegenerative Alzheimer-like pathology in PDAPP 717V$>\mathrm{F}$ transgenic mice. In: Hyman B, Duyckaerts C, Christen Y (eds) Connections, cognition and Alzheimer's disease. Springer, Berlin, pp 105-119

Glabe CC (2005) Amyloid accumulation and pathogenesis of Alzheimer's disease: significance of monomeric, oligomeric and fibrillar Abeta. Subcell Biochem 38:167-177

Glabe CG, Kayed R (2006) Common structure and toxic function of amyloid oligomers implies a common mechanism of pathogenesis. Neurology 66:S74-S78

Haughey NJ, Nath A, Chan SL, Borchard AC, Rao MS, Mattson MP (2002) Disruption of neurogenesis by amyloid beta-peptide, and perturbed neural progenitor cell homeostasis, in models of Alzheimer's disease. J Neurochem 83:1509-1524

Herzig MC, Winkler DT, Burgermeister P, Pfeifer M, Kohler E, Schmidt SD, Danner S, Abramowski D, Sturchler-Pierrat C, Burki K, van Duinen SG, Maat-Schieman ML, Staufenbiel M, Mathews PM, Jucker M (2004) Abeta is targeted to the vasculature in a mouse model of hereditary cerebral hemorrhage with amyloidosis. Nat Neurosci 7:954-960

Herzig MC, Van Nostrand WE, Jucker M (2006) Mechanism of cerebral beta-amyloid angiopathy: murine and cellular models. Brain Pathol 16:40-54

Herzig MC, Eisele YS, Staufenbiel M, Jucker M (2009) E22Q-mutant Abeta peptide (AbetaDutch) increases vascular but reduces parenchymal Abeta deposition. Am J Pathol 174:722-726

Hof P, Morrison J (1994) The cellular basis of cortical disconnection in Alzheimer disease and related dementing conditions. In: Terry R, Katzman R, Bick K (eds) Alzheimer disease. Raven Press, New York, pp 197-230

Hof P, Cox K, Morrison J (1990) Quantitative analysis of a vulnerable subset of pyramidal neurons in Alzheimer's disease: I. Superior frontal and inferior temporal cortex. J Comp Neurol 301:44-54

Holcomb L, Gordon M, McGowan E, Yu X, Benkovic S, Jantzen P, Wright K, Saad I, Mueller R, Morgan D, Sanders P, Zehr C, O'Campo K, Hardy J, Prada C-M, Eckman C, Younkin S, Hsiao K, Duff K (1998) Accelerated Alzheimer-type phenotype in transgenic mice carrying both mutant amyloid precursor protein and presenilin 1 transgenes. Nature Med 4:97-100

Holtzman DM, Pitas RE, Kilbridge J, Nathan B, Mahley RW, Bu G, Schwartz AL (1995) Low density lipoprotein receptor-related protein mediates apolipoprotein E-dependent neurite outgrowth in a central nervous system-derived neuronal cell line. Proc Natl Acad Sci USA 92:9480-9484

Holtzman DM, Bales KR, Wu S, Bhat P, Parsadanian M, Fagan AM, Chang LK, Sun Y, Paul SM (1999) Expression of human apolipoprotein $\mathrm{E}$ reduces amyloid- $\beta$ deposition in a mouse model of Alzheimer's disease. J Clin Invest 103:R15-R21

Honer WG (2003) Pathology of presynaptic proteins in Alzheimer's disease: more than simple loss of terminals. Neurobiol Aging 24:1047-1062

Hsia AY, Masliah E, McConlogue L, Yu G-Q, Tatsuno G, Hu K, Kholodenko D, Malenka RC, Nicoll RA, Mucke L (1999) Plaque-independent disruption of neural circuits in Alzheimer's disease mouse models. Proc Natl Acad Sci USA 96:3228-3233

Hsiao K, Chapman P, Nilsen S, Eckman C, Harigaya Y, Younkin S, Yang F, Cole G (1996) Correlative memory deficits, Abeta elevation, and amyloid plaques in transgenic mice. Science 274:99-102

Hutton M, Hardy J (1997) The presenilins and Alzheimer's disease. Hum Mol Genet 6:1639-1646

Hyman B, VanHoesen G, Damasio A, Barnes C (1984) Alzheimer's disease: Cell-specific pathology isolates the hippocampal formation. Science 225:1168-1170 
Irizarry M, Soriano F, McNamara M, Page K, Schenk D, Games D, Hyman B (1997a) Abeta deposition is associated with neuropil changes, but not with overt neuronal loss in the human amyloid precursor protein V717F (PDAPP) transgenic mouse. J Neurosci 17:7053-7059

Irizarry MC, McNamara M, Fedorchak K, Hsiao K, Hyman BT (1997b) APPSw transgenic mice develop age-related A beta deposits and neuropil abnormalities, but no neuronal loss in CA1. J Neuropathol Exp Neurol 56:965-973

Iwata N, Tsubuki S, Takaki Y, Watanabe K, Sekiguchi M, Hosoki E, Kawashima-Morishima M, Lee HJ, Hama E, Sekine-Aizawa Y, Saido TC (2000) Identification of the major Abeta1-42-degrading catabolic pathway in brain parenchyma: suppression leads to biochemical and pathological deposition. Nat Med 6:143-150

Iwata N, Tsubuki S, Takaki Y, Shirotani K, Lu B, Gerard NP, Gerard C, Hama E, Lee HJ, Saido TC (2001) Metabolic regulation of brain Abeta by neprilysin. Science 292:1550-1552

Jankowsky JL, Slunt HH, Gonzales V, Savonenko AV, Wen JC, Jenkins NA, Copeland NG, Younkin LH, Lester HA, Younkin SG, Borchelt DR (2005) Persistent amyloidosis following suppression of Abeta production in a transgenic model of Alzheimer disease. PLoS Med 2:e355

Jessberger S, Aigner S, Clemenson GD Jr, Toni N, Lie DC, Karalay O, Overall R, Kempermann G, Gage FH (2008) Cdk5 regulates accurate maturation of newborn granule cells in the adult hippocampus. PLoS Biol 6:e272

Jin K, Galvan V, Xie L, Mao XO, Gorostiza OF, Bredesen DE, Greenberg DA (2004) Enhanced neurogenesis in Alzheimer's disease transgenic (PDGF-APPSw, Ind) mice. Proc Natl Acad Sci USA 101:13363-13367

Johnson MA, Ables JL, Eisch AJ (2009) Cell-intrinsic signals that regulate adult neurogenesis in vivo: insights from inducible approaches. BMB Rep 42:245-259

Klein WL, Krafft GA, Finch CE (2001) Targeting small Abeta oligomers: the solution to an Alzheimer's disease conundrum? Trends Neurosci 24:219-224

Klyubin I, Betts V, Welzel AT, Blennow K, Zetterberg H, Wallin A, Lemere CA, Cullen WK, Peng Y, Wisniewski T, Selkoe DJ, Anwyl R, Walsh DM, Rowan MJ (2008) Amyloid beta protein dimer-containing human CSF disrupts synaptic plasticity: prevention by systemic passive immunization. J Neurosci 28:42314237

Koo E, Lansbury PJ, Kelly J (1999) Amyloid diseases: abnormal protein aggregation in neurodegeneration. Proc Natl Acad Sci USA 96:9989-9990

Lacor PN, Buniel MC, Chang L, Fernandez SJ, Gong Y, Viola KL, Lambert MP, Velasco PT, Bigio EH, Finch CE, Krafft GA, Klein WL (2004) Synaptic targeting by Alzheimer's-related amyloid beta oligomers. J Neurosci 24:10191-10200

Lacor PN, Buniel MC, Furlow PW, Clemente AS, Velasco PT, Wood M, Viola KL, Klein WL (2007) Abeta oligomer-induced aberrations in synapse composition, shape, and density provide a molecular basis for loss of connectivity in Alzheimer's disease. J Neurosci 27:796-807

LaFerla FM, Green KN, Oddo S (2007) Intracellular amyloid-beta in Alzheimer's disease. Nat Rev Neurosci 8:499-509

Lagace DC, Benavides DR, Kansy JW, Mapelli M, Greengard P, Bibb JA, Eisch AJ (2008) Cdk5 is essential for adult hippocampal neurogenesis. Proc Natl Acad Sci USA 105:18567-18571

Lansbury PT Jr (1999) Evolution of amyloid: what normal protein folding may tell us about fibrillogenesis and disease. Proc Natl Acad Sci USA 96:3342-3344

Lashuel HA, Hartley DM, Petre BM, Wall JS, Simon MN, Walz T, Lansbury PT Jr (2003) Mixtures of wild-type and a pathogenic (E22G) form of Abeta40 in vitro accumulate protofibrils, including amyloid pores. J Mol Biol 332:795-808
Lee MS, Kwon YT, Li M, Peng J, Friedlander RM, Tsai LH (2000) Neurotoxicity induces cleavage of p 35 to p 25 by calpain. Nature 405:360-364

Leissring MA, Farris W, Chang AY, Walsh DM, Wu X, Sun X, Frosch MP, Selkoe DJ (2003) Enhanced proteolysis of beta-amyloid in APP transgenic mice prevents plaque formation, secondary pathology, and premature death. Neuron 40:1087-1093

Lesne S, Koh MT, Kotilinek L, Kayed R, Glabe CG, Yang A, Gallagher M, Ashe KH (2006) A specific amyloid-beta protein assembly in the brain impairs memory. Nature 440:352-357

Levy E, Carman MD, Fernandez-Madrid IJ, Power MD, Lieberburg I, van Duinen SG, Bots GT, Luyendijk W, Frangione B (1990) Mutation of the Alzheimer's disease amyloid gene in hereditary cerebral hemorrhage, Dutch type. Science 248:1124-1126

Lie DC, Colamarino SA, Song HJ, Desire L, Mira H, Consiglio A, Lein ES, Jessberger S, Lansford H, Dearie AR, Gage FH (2005) Wnt signalling regulates adult hippocampal neurogenesis. Nature 437:1370-1375

Lim DA, Tramontin AD, Trevejo JM, Herrera DG, Garcia-Verdugo JM, Alvarez-Buylla A (2000) Noggin antagonizes BMP signaling to create a niche for adult neurogenesis. Neuron 28:713-726

Luo JJ, Wallace W, Riccioni T, Ingram DK, Roth GS, Kusiak JW (1999) Death of PC12 cells and hippocampal neurons induced by adenoviral-mediated FAD human amyloid precursor protein gene expression. J Neurosci Res 55:629-642

Marr RA, Guan H, Rockenstein E, Kindy M, Gage FH, Verma I, Masliah E, Hersh LB (2004) Neprilysin regulates amyloid Beta peptide levels. J Mol Neurosci 22:5-11

Masliah E (1998) The role of synaptic proteins in neurodegenerative disorders. Neurosci News 1:14-20

Masliah E (2000) The role of synaptic proteins in Alzheimer's disease. Ann N Y Acad Sci 924:68-75

Masliah E (2001) Recent advances in the understanding of the role of synaptic proteins in Alzheimer's disease and other neurodegenerative disorders. J Alzheimers Dis 3:121-129

Masliah E, Terry R (1993) The role of synaptic proteins in the pathogenesis of disorders of the central nervous system. Brain Pathol 3:77-85

Masliah E, Terry R (1994) The role of synaptic pathology in the mechanisms of dementia in Alzheimer's disease. Clin Neurosci 1:192-198

Masliah E, Mallory M, Hansen L, Alford M, Albright T, Terry R, Shapiro P, Sundsmo M, Saitoh T (1991) Immunoreactivity of CD45, a protein phosphotyrosine phosphatase, in Alzheimer disease. Acta Neuropathol 83:12-20

Masliah E, Mallory M, Hansen L, Alford M, DeTeresa R, Terry R (1993) An antibody against phosphorylated neurofilaments identifies a subset of damaged association axons in Alzheimer's disease. Am J Pathol 142:871-882

Masliah E, Sisk A, Mallory M, Mucke L, Schenk D, Games D (1996) Comparison of neurodegenerative pathology in transgenic mice overexpressing V717F b-amyloid precursor protein and Alzheimer's disease. J Neurosci 16:5795-5811

Masliah E, Mallory M, Alford M, DeTeresa R, Hansen LA, McKeel DW Jr, Morris JC (2001) Altered expression of synaptic proteins occurs early during progression of Alzheimer's disease. Neurology 56:127-129

Moechars D, Dewachter I, Lorent K, Reverse D, Baekelandt V, Naidu A, Tesseur I, Spittaels K, van den Haute C, Checler F, Godaux E, Cordell B, Van Leuven F (1999) Early phenotypic changes in transgenic mice that overexpress different mutants of amyloid precursor protein in brain. J Biol Chem 274:6483-6492

Moolman DL, Vitolo OV, Vonsattel JP, Shelanski ML (2004) Dendrite and dendritic spine alterations in Alzheimer models. J Neurocytol 33:377-387 
Mucke L, Masliah E, Yu GQ, Mallory M, Rockenstein EM, Tatsuno G, Hu K, Kholodenko D, Johnson-Wood K, McConlogue L (2000) High-level neuronal expression of abeta 1-42 in wildtype human amyloid protein precursor transgenic mice: synaptotoxicity without plaque formation. J Neurosci 20:4050-4058

Nalbantoglu J, Tirado-Santiago G, Lahsaini A, Poirier J, Goncalves O, Verge G, Momoli F, Welner S, Massicotte G, Julien J (1997) Impaired learning and LTP in mice expressing the carboxy terminus of the Alzheimer amyloid precursor protein. Nature 387:500-505

Nixon RA, Cataldo AM, Paskevich PA, Hamilton DJ, Wheelock TR, Kanaley-Andrews L (1992) The lysosomal system in neurons. Involvement at multiple stages of Alzheimer's disease pathogenesis. Ann N Y Acad Sci 674:65-88

Nixon RA, Wegiel J, Kumar A, Yu WH, Peterhoff C, Cataldo A, Cuervo AM (2005) Extensive involvement of autophagy in Alzheimer disease: an immuno-electron microscopy study. J Neuropathol Exp Neurol 64:113-122

Oddo S, Caccamo A, Kitazawa M, Tseng BP, LaFerla FM (2003a) Amyloid deposition precedes tangle formation in a triple transgenic model of Alzheimer's disease. Neurobiol Aging 24:1063-1070

Oddo S, Caccamo A, Shepherd JD, Murphy MP, Golde TE, Kayed R, Metherate R, Mattson MP, Akbari Y, LaFerla FM (2003b) Triple-transgenic model of Alzheimer's disease with plaques and tangles: intracellular Abeta and synaptic dysfunction. Neuron 39:409-421

Palmer A, Gershon S (1990) Is the neuronal basis of Alzheimer's disease cholinergic or glutamatergic? FASEB J 4:2745-2752

Pastor P, Goate AM (2004) Molecular genetics of Alzheimer's disease. Curr Psychiatry Rep 6:125-133

Perry E, Perry R, Blessed G, Tomlinson B (1977) Neurotransmitter enzyme abnormalities in senile dementia: CAT and GAD activities in necropsy tissue. J Neurol Sci 34:247-265

Pezzini A, Del Zotto E, Volonghi I, Giossi A, Costa P, Padovani A (2009) Cerebral amyloid angiopathy: a common cause of cerebral hemorrhage. Curr Med Chem 16:2498-2513

Price D, Martin L, Sisodia S, Walker L, Voytko M, Wagster M, Cork L, Koliatsos V (1994) The aged nonhuman primate. A model for the behavioral and brain abnormalities occurring in aged humans. In: Terry R, Katzman R, Bick K (eds) Alzheimer disease. Raven Press, New York, pp 231-245

Price DL, Wong PC, Markowska AL, Lee MK, Thinakaren G, Cleveland DW, Sisodia SS, Borchelt DR (2000) The value of transgenic models for the study of neurodegenerative diseases. Ann N Y Acad Sci 920:179-191

Raff MC, Whitmore AV, Finn JT (2002) Axonal self-destruction and neurodegeneration. Science 296:868-871

Ramassamy C, Averill D, Beffert U, Bastianetto S, Theroux L, Lussier-Cacan S, Cohn JS, Christen Y, Davignon J, Quirion R, Poirier J (1999) Oxidative damage and protection by antioxidants in the frontal cortex of Alzheimer's disease is related to the apolipoprotein E genotype. Free Rad Biol Med 27:544-553

Reaume A, Howland D, Trusko S, Savage M, Lang D, Greenberg B, Siman R, Scott R (1996) Enhanced amyloidogenic processing of the beta-amyloid precursor protein in gene-targeted mice bearing the Swedish familial Alzheimer's disease mutations and a "humanized" Abeta sequence. J Biol Chem 271:23380-23388

Rocchi A, Pellegrini S, Siciliano G, Murri L (2003) Causative and susceptibility genes for Alzheimer's disease: a review. Brain Res Bull 61:1-24

Rockenstein E, McConlogue L, Tan H, Power M, Masliah E, Mucke L (1995) Levels and alternative splicing of amyloid b protein precursor (APP) transcripts in brains of APP transgenic mice and humans with Alzheimer's disease. J Biol Chem 270:2825728267

Rockenstein E, Mallory M, Mante M, Sisk A, Masliah E (2001) Early formation of mature amyloid-b proteins deposits in a mutant APP transgenic model depends on levels of Ab1-42. J Neurosci Res 66:573-582

Rockenstein E, Mante M, Adame A, Crews L, Moessler H, Masliah E (2007) Effects of Cerebrolysintrade mark on neurogenesis in an APP transgenic model of Alzheimer's disease. Acta Neuropathol (Berl) 113:265-275

Rogers J, Luber-Narod J, Styren S, Civin W (1988) Expression of immune system-associated antigens by cells of the human central nervous system: relationship to the pathology of Alzheimer's disease. Neurobiol Aging 9:339-349

Saito T, Iwata N, Tsubuki S, Takaki Y, Takano J, Huang SM, Suemoto T, Higuchi M, Saido TC (2005) Somatostatin regulates brain amyloid beta peptide Abeta42 through modulation of proteolytic degradation. Nat Med 11:434-439

Scheff SW, Price DA (2001) Alzheimer's disease-related synapse loss in the cingulate cortex. J Alzheimers Dis 3:495-505

Scheff SW, Price DA (2003) Synaptic pathology in Alzheimer's disease: a review of ultrastructural studies. Neurobiol Aging 24:1029-1046

Schilling S, Zeitschel U, Hoffmann T, Heiser U, Francke M, Kehlen A, Holzer M, Hutter-Paier B, Prokesch M, Windisch M, Jagla W, Schlenzig D, Lindner C, Rudolph T, Reuter G, Cynis H, Montag D, Demuth HU, Rossner S (2008) Glutaminyl cyclase inhibition attenuates pyroglutamate Abeta and Alzheimer's disease-like pathology. Nat Med 14:1106-1111

Selkoe DJ (2000) The genetics and molecular pathology of Alzheimer's disease: roles of amyloid and the presenilins. Neurol Clin 18:903-922

Selkoe DJ (2001) Clearing the brain's amyloid cobwebs. Neuron $32: 177-180$

Selkoe DJ (2008) Soluble oligomers of the amyloid beta-protein impair synaptic plasticity and behavior. Behav Brain Res 192:106-113

Selkoe DJ, Yamazaki T, Citron M, Podlisny MB, Koo EH, Teplow DB, Haass C (1996) The role of APP processing and trafficking pathways in the formation of amyloid beta-protein. Ann N Y Acad Sci 777:57-64

Siman R, Reaume AG, Savage MJ, Trusko S, Lin YG, Scott RW, Flood DG (2000) Presenilin-1 P264L knock-in mutation: differential effects on abeta production, amyloid deposition, and neuronal vulnerability. J Neurosci 20:8717-8726

Sinha S, Anderson JP, Barbour R, Basi GS, Caccavello R, Davis D, Doan M, Dovey HF, Frigon N, Hong J, Jacobson-Croak K, Jewett N, Keim P, Knops J, Lieberburg I, Power M, Tan H, Tatsuno G, Tung J, Schenk D, Seubert P, Suomensaari SM, Wang S, Walker D, John V et al (1999) Purification and cloning of amyloid precursor protein beta-secretase from human brain. Nature 402:537-540

Sturchler-Pierrat C, Abramowski D, Duke M, Wiederholt K, Mistl C, Rothacher S, Ledermann B, Burki K, Frey P, Paganetti P, Waridel C, Calhoun M, Jucker M, Probst A, Staufenbiel M, Sommer B (1997) Two amyloid precursor protein transgenic mouse models with Alzheimer disease-like pathology. Proc Natl Acad Sci USA 94:13287-13292

Tatebayashi Y, Lee MH, Li L, Iqbal K, Grundke-Iqbal I (2003) The dentate gyrus neurogenesis: a therapeutic target for Alzheimer's disease. Acta Neuropathol (Berl) 105:225-232

Terry RD, Masliah E, Salmon DP, Butters N, DeTeresa R, Hill R, Hansen LA, Katzman R (1991) Physical basis of cognitive alterations in Alzheimer's disease: synapse loss is the major correlate of cognitive impairment. Ann Neurol 30:572-580 
Terry R, Hansen L, Masliah E (1994) Structural basis of the cognitive alterations in Alzheimer disease. In: Terry R, Katzman R (eds) Alzheimer disease. Raven Press, New York, pp 179-196

Townsend M, Shankar GM, Mehta T, Walsh DM, Selkoe DJ (2006) Effects of secreted oligomers of amyloid beta-protein on hippocampal synaptic plasticity: a potent role for trimers. J Physiol 572:477-492

Trojanowski JQ, Lee VM (2000) "Fatal attractions" of proteins A comprehensive hypothetical mechanism underlying Alzheimer's disease and other neurodegenerative disorders. Ann N Y Acad Sci 924:62-67

Tsubuki S, Takaki Y, Saido TC (2003) Dutch, Flemish, Italian, and Arctic mutations of APP and resistance of Abeta to physiologically relevant proteolytic degradation. Lancet 361:1957-1958

van Duinen SG, Castano EM, Prelli F, Bots GT, Luyendijk W, Frangione B (1987) Hereditary cerebral hemorrhage with amyloidosis in patients of Dutch origin is related to Alzheimer disease. Proc Natl Acad Sci USA 84:5991-5994

van Leeuwen F, de Kleijn D, van den Hurk H, Neubauer A, Sonnemans M, Sluijs J, Keoyceau S, Ramdjielal R, Salehi A, Martens G, Grosveld F, Peter J, Burbach H, Hol E (1998) Frameshift mutants of beta amyloid precursor protein and ubiquitin-B in Alzheimer's and Down patients. Science 279:242-247

van Praag H, Schinder AF, Christie BR, Toni N, Palmer TD, Gage FH (2002) Functional neurogenesis in the adult hippocampus. Nature 415:1030-1034

Vassar R, Bennett BD, Babu-Khan S, Kahn S, Mendiaz EA, Denis P, Teplow DB, Ross S, Amarante P, Loeloff R, Luo Y, Fisher S, Fuller J, Edenson S, Lile J, Jarosinski MA, Biere AL, Curran E, Burgess T, Louis JC, Collins F, Treanor J, Rogers G, Citron M (1999) Beta-secretase cleavage of Alzheimer's amyloid precursor protein by the transmembrane aspartic protease BACE. Science 286:735-741
Volles MJ, Lansbury PT Jr (2002) Vesicle permeabilization by protofibrillar alpha-synuclein is sensitive to Parkinson's diseaselinked mutations and occurs by a pore-like mechanism. Biochemistry 41:4595-4602

Volles MJ, Lee SJ, Rochet JC, Shtilerman MD, Ding TT, Kessler JC, Lansbury PT Jr (2001) Vesicle permeabilization by protofibrillar alpha-synuclein: implications for the pathogenesis and treatment of Parkinson's disease. Biochemistry 40:7812-7819

Walsh DM, Selkoe DJ (2004) Oligomers on the brain: the emerging role of soluble protein aggregates in neurodegeneration. Protein Pept Lett 11:213-228

Walsh D, Tseng B, Rydel R, Podlisny M, Selkoe D (2000) The oligomerization of amyloid beta-protein begins intracellularly in cells derived from human brain. Biochemistry 39:10831-10839

Walsh DM, Klyubin I, Fadeeva JV, Rowan MJ, Selkoe DJ (2002) Amyloid-beta oligomers: their production, toxicity and therapeutic inhibition. Biochem Soc Trans 30:552-557

Wang R, Dineley KT, Sweatt JD, Zheng H (2004) Presenilin 1 familial Alzheimer's disease mutation leads to defective associative learning and impaired adult neurogenesis. Neuroscience 126:305-312

Wen PH, Hof PR, Chen X, Gluck K, Austin G, Younkin SG, Younkin LH, DeGasperi R, Gama Sosa MA, Robakis NK, Haroutunian V, Elder GA (2004) The presenilin-1 familial Alzheimer disease mutant P117L impairs neurogenesis in the hippocampus of adult mice. Exp Neurol 188:224-237

Wilcock GK, Esiri MM, Bowen DM, Hughes AO (1988) The differential involvement of subcortical nuclei in senile dementia of Alzheimer's type. J Neurol Neurosurg Psychiatry 51:842-849

Wirths O, Breyhan H, Cynis H, Schilling S, Demuth HU, Bayer TA (2009) Intraneuronal pyroglutamate-Abeta 3-42 triggers neurodegeneration and lethal neurological deficits in a transgenic mouse model. Acta Neuropathol 118(4):487-496 